\title{
KEBERADAAN ETNIS BANJAR DI DESA TELADAN KECAMATAN TINGGI RAJA KABUPATEN ASAHAN
}

\author{
Oleh: \\ Ponirin \\ Hariyati
}

\begin{abstract}
Abstrak
Penelitian ini bertujuan untuk mengetahui (a) Sejarah keberadaan Etnis Banjar di Desa Teladan Kecamatan Tinggi Raja Kabupaten Asahan (b) Proses adaptasi Etnis Banjar di Desa Teladan Kecamatan Tinggi Raja Kabupaten Asahan (c) Dampak Adaptasi Etnis Banjar di Desa Teladan Kecamatan Tinggi Raja Kabupaten Asahan. Dalam penelitian ini penulis menggunakan pendekatan penelitian deskriptif kualitatif. Untuk memperoleh data yang dibutuhkan, peneliti menggunakan metode penelitian lapangan (field research) yang dimana peneliti langsung terjun ke lapangan dan memperoleh data melalui wawancara, observasi dan dokumentasi. Metode lainnya yang digunakan dalam penelitian ini yaitu dengan menggunakan metode study kepustakaan (library reserch) dengan mengumpulkan buku-buku yang berkaitan dengan judul penelitian. Dari hasil penelitian yang dilakukan peneliti maka dapat diketahui bahwa keberadaan Etnis Banjar di Desa Teladan telah ada sejak abad ke-20. Yang membuat mereka sengaja datang dikarenakan terjadinya perang Banjar di wilayah asal, dan wilayah mereka tidak stabil serta sulit untuk mengembangkan usaha dagangnya maupun pertaniannya. Sehingga mereka datang ke daerah-daerah tertentu untuk mencari ketenangan hidupnya. Orang Banjar yang datang ke Desa Teladan dikarenakan tanahnya yang subur dan sangat cocok untuk dijadikan lahan pertanian serta untuk menghemat biaya hidup. Dari hasil pertanian tersebut kemudian di perdagangkan dengan orang-orang disekitar Asahan bahkan di luar Asahan. Proses adaptasi Etnis Banjar di Desa Teladan dengan cara digunakannya bahasa Indonesia dan bahasa Jawa sebagai bahasa pergaulan sehari-hari. Sedangkan dari adanya adaptasi membawa dampak bagi masyarakat Etnis Jawa yang berada di Desa Teladan dari 7 unsur Kebudayaan, seperti pada sistem kepercayaan, sistem mata pencaharian, kesenian, bahasa, sistem ilmu pengetahuan sistem teknologi dan peralatan hidup, serta sistem kekerabatan dan organisasi sosial semuanya sudah mengalami perubahan karena sudah terakulturasi dengan budaya etnis yang ada di Desa Teladan, khususnya etnis Jawa.
\end{abstract}

Kata Kunci: Eksistensi, Etnis Banjar. 


\section{I.PENDAHULUAN}

Indonesia adalah sebuah negara yang masyarakatnya terdiri dari berbagai macam etnis dengan kekayaan budaya yang beragam. Di Indonesia banyak terdapat suku bangsa yang unik dan menarik untuk diteliti, karena terdapat puluhan hingga ratusan suku bangsa, dimana suku bangsa itu mendiami daerahnya masing-masing, ada yang sudah bermigrasi ke luar daerah asalnya, dan ada juga yang masih utuh keasliannya, serta ada pula yang sudah punah keaslian dan karakternya.

Etnis Banjar atau yang sering disebut urang Banjar merupakan etnis pendatang yang berasal dari Kalimantan yang sebagian besar menempati wilayah provinsi Kalimantan Selatan, dan di Kalimantan Tengah, Kalimantan Timur. Populasi etnis Banjar dalam jumlah yang besar juga dapat di temui di wilayah Riau, Jambi, Sumatera Utara, serta Semenanjung Malaysia.

Kehadiran orang Banjar ke Sumatera diakibatkan peperangan melawan Belanda dalam perang Banjar awal abad ke-20 yaitu pada tahun 1905. Orang Banjar terpaksa melakukan migrasi karena Sultan Muhammad Seman yang menjadi raja di Kerajaan Banjar itu mati syahid di tangan Belanda. Dengan adanya perang tersebut wilayah tempat tinggal orang Banjar tidak stabil. Orang Banjar sulit untuk memenuhi kebutuhan sehari-hari mereka dan ekonominya. Apalagi daerah orang Banjar kurang produktif untuk pertanian karena sebagian besar merupakan rawarawa dan hutan. Sehingga orang Banjar sulit untuk bertani. Mereka juga datang ke daerah-daerah tertentu di Sumatera Utara di daerah Kabupaten Langkat, Deli Serdang, Serdang Bedagai, Asahan dan Labuhan Batu. Sedangkan di kabupaten Asahan orang Banjar yang datang dari Kalimantan Selatan yang merupakan pelaut dan pedagang antar pulau sebelumnya menetap di pantai Timur Aceh dan Langkat. Tetapi karena mereka ingin mencari lahan yang lebih subur dan mengembangkan jiwa dagangnya kemudian mereka menyisir pantai dan memutuskan untuk mendarat di Asahan. Setelah itu mereka menetap di Asahan, di Asahan mereka bertani dan berdagang demi kelangsungan hidup mereka yang diharapkan semakin membaik dari sebelumnya.

Orang Banjar di Asahan juga menyebar di kecamatan-kecamatan yang ada di Kabupaten Asahan. Khususnya di kecamatan Tinggi Raja. orang Banjar yang 
datang ke Tinggi Raja dikarenakan tanahnya yang subur dan sangat cocok untuk dijadikan lahan pertanian. Dari hasil pertanian tersebut kemudian di perdagangkan dengan orang-orang disekitar Asahan bahkan di luar Asahan. Sehingga tidak heran kalau orang Banjar yang berada di Asahan terbilang cukup banyak yang tinggal di Desa Teladan Kecamatan Tinggi Raja dengan jumlah 132 orang jika dibandingkan dengan etnis Banjar yang tinggal di Desa Aek Nagali Kecamatan Bandar Pulau yang hanya berjumlah 8 orang.

Orang-orang Banjar yang tinggal di Desa Teladan Kecamatan Tinggi Raja sekarang sudah hidup membaur dan harmonis dengan etnis lainnya yang tinggal di Desa Teladan, yaitu etnis Jawa dan etnis Batak. Orang Banjar juga terbilang sangat mudah beradaptasi dengan etnis lainnya di karenakan mereka sangat ramah, dan suka menolong tanpa membeda-bedakan etnis. Berdasarkan hasil observasi awal dalam beradaptasi orang Banjar menyesuaikan dengan masyarakat etnis lainnya yang tinggal di Desa Teladan. Seperti berinteraksi mereka menyesuaikannya dengan bahasa yang digunakan sehari-hari oleh masyarakat etnis lainnya di Desa Teladan, yaitu bahasa Jawa jika berbicara dengan orang Jawa, dan bahasa batak jika berbicara dengan orang Batak. walaupun masih belum fasih mereka tetap mencoba berbahasa daerah dangan etnis lainnya yang tinggal di Desa Teladan. Namun mereka tetap diperbolehkan berbahasa Indonesia. Karena di daerah Desa Teladan Kecamatan Tinggi Raja Kabupaten Asahan ini cirinya adalah orang Jawa lebih dominan berjumlah sembilan puluh persen, sehingga etnis-etnis yang lain seperti Banjar beradaptasi dengan orang Jawa. Maka dengan orang Banjar beradaptasi dengan masyarakat Jawa, tentunya membawa dampak bagi masyarakat etnis Banjar yang datang di Desa Teladan Kecamatan Tinggi Raja Kabupaten Asahan. Orang Banjar lama kelamaan tidak bisa mempertahan budaya dan bahasanya dan dalam hal ini juga terjadi akulturasi budaya. Seperti adat istiadat dalam pernikahan, seni, maupun tradisi mereka sudah pudar.

Adapun Jenis penelitian ini yaitu deskriptif kualitatif. Menurut Lexy J. Moleong (2012:6) Penelitian kualitatif adalah penelitian yang menghasilkan prosedur analisis yang tidak menggunakan prosedur analisis statistik atau cara kuantitatif lainnya. Lexy J. Moleong (2012:9) mengemukakan bahwa penelitian 
kualitatif menggunakan metode kualitatif yaitu pengamatan, wawancara, atau penelaahan dokumen

Dalam penelitian ini juga terdapat 2 metode peneliti yaitu, Penelitian lapangan (field research) Yaitu dengan cara mengumpulkan data-data secara objektif berdasarkan hasil dari wawancara dengan masyarakat etnis Banjar di sekitar Desa Teladan Kecamatan Tinggi Raja Kabupaten Asahan. Selanjutnya Penelitian keperpustakaan (library research). Penelitian ini juga dikombinasikan dengan penelitian keperpustakaan (library research). Yaitu dengan cara mengkaitkan penelitian lapangan (field research) dengan tulisan-tulisan yang berhubungan dengan judul penelitian mengenai Keberadaan Etnis Banjar di Desa Teladan Kecamatan Tinggi Raja Kabupaten Asahan.

Yang menjadi lokasi penelitian peneliti yaitu Desa Teladan Kecamatan Tinggi Raja Kabupaten Asahan. Penelitian diambil dilokasi ini dikarenakan bahwa Desa Teladan Kecamatan Tinggi Raja Kabupaten Asahan merupakan Desa yang masyarakatnya etnis Banjar merupakan masyarakat pendatang yang paling sedikit di Desa Teladan jika dibandingkan dengan etnis lainnya yang berada di Desa Teladan Kecamatan Tinggi Raja Kabupatean Asahan ini. Dengan demikian peneliti tertarik ingin mengetahui Keberadaan Etnis Banjar di Desa Teladan Kecamatan Tinggi Raja Kabupaten Asahan.

Adapun yang menjadi Populasi dalam penelitian ini adalah masyarakat Banjar yang berada di Desa Teladan Kecamatan Tinggi Raja Kabupaten Asahan yang berjumlah 132 jiwa (Data Kantor Desa Teladan Tahun 2018). Sedangkan pengambilan sampel dilakukan dengan menggunakan model snowball. Dengan cara menanyakan kepada narasumber pertama, yaitu orang Banjar yang paling lama tinggal di Desa Teladan Kecamatan Tinggi Raja Kabupaten Asahan mengenai siapa selanjutnya narasumber yang akan peneliti wawancarai sampai data selesai. Dan yang menjadi sampel dalam penelitian ini yaitu Orang Banjar yang paling lama tinggal di Desa Teladan Kecamatan Tinggi Raja Kabupaten Asahan, dan warga lainnya yang memberikan informasi mengenai judul penelitian.

Dalam penelitian ini peneliti menggunakan sumber yaitu: Data Primer. Data primer dalam penelitian ini yaitu data yang berhubungan langsung dengan peristiwa 
atau kejadian yang berkaitan dengan etnis Banjar di Desa Teladan Kecamatan Tinggi Raja Kabupaten Asahan yang diperoleh dari informan yang merupakan orang Banjar pertama di Desa Teladan atau keturunannya yang bermukim di Desa Teladan yang, dalam hal ini merupakan informan atau orang Banjar yang dituakan di wilayah Desa Teladan Kecamaatn Tinggi Raja, dan data tertulis yang diambil dari kantor desa mengenai kependudukan Desa Teladan Kecamatan Tinggi Raja Kabupaten Asahan. Data Sekunder, Adapun yang menjadi data sekunder dalam penelitian ini yaitu literatur berupa: Buku-buku ataupun hasil penelitian yang berkaitan tentang Keberadaan Etnis Banjar di Desa Teladan Kecamatan Tinggi Raja Kabupaten Asahan.

Dalam pengumpulan data yang dibutuhkan peneliti menggunakan 3 metode untuk mendapatkan data yang kongkrit dan objektif, diantaranya yaitu: Observasi, dengan cara pengamatan secara langsung yang dilakukan di lokasi tempat pemukiman masyarakat Banjar berada. Dan mengamati bagaimana masyarakat etnis Banjar beradaptasi dan apa dampak yang terjadi setelah masyarakat etnis Banjar beradaptasi. Metode wawancara yaitu proses untuk memperoleh keterangan secara langsung dengan cara melakukan wawancara dengan masyarakat etnis Banjar yang telah lama tinggal di Desa Teladan Kecamatan Tinggi Raja Kabupaten Asahan atau orang Banjar yang dituakan di Desa Teladan Kecamatan Tinggi Raja Kabupaten Asahan dan masyarakat lainnya yang dapat memberikan informasi mengenai judul penelitian peneliti tentang Keberadaan Etnis Banjar di Desa Teladan Kecamatan Tinggi Raja Kabupaten Asahan. Yaitu kepada narasumber yang bernama Ibu Hadijah, Ibu Nila, Bapak Alinafiah, Ibu Salbiah dan bapak Husein. Dokumentasi yaitu pengumpulan data atau informasi yang diperoleh dari keperpustakaan tertulis, dokumentasi dari kantor kepala desa, beserta foto-foto yang diperoleh dari setiap narasumber masyarakat etnis Banjar yang berada di Desa Teladan Kecamatan Tinggi Raja Kabupaten Asahan pada saat penelitian dilakukan peneliti. Berupa objek kegiatan masyarakat Banjar saat beradaptasi dan melakukan pekerjaan sehari-harinya. 


\section{PEMBAHASAN}

Sejarah etnis Banjar di Desa Teladan kecamatan Tinggi Raja ini dapat ditelusuri melalui bagaimana awal keberadaan etnis Banjar tersebut datang. Migrasi Etnis Banjar di Desa Teladan tidak bisa dipisahkan dari asal tempat tinggal asli mereka, yaitu di Kalimantan. Awal masyarakat etnis Banjar sebelum bermigrasi ke Desa Teladan Kecamatan Tinggi Raja ini dikarenakan terjadi perang Banjar di Kalimantan awal abad ke-20 yaitu pada tahun 1905. Orang Banjar terpaksa melakukan migrasi karena Sultan Muhammad Seman yang menjadi raja di Kerajaan Banjar itu mati syahid di tangan Belanda. Dengan adanya perang tersebut wilayah tempat tinggal orang Banjar tidak stabil. Mereka sulit untuk memenuhi kebutuhan sehari-hari mereka dan ekonomi mereka. Apalagi daerah orang Banjar kurang produktif untuk pertanian karena sebagian besar merupakan rawa-rawa dan hutan. Sehingga orang Banjar sulit untuk bertani. Untuk bertahan hidup sebagian dari mereka memutuskan untuk bermigrasi ke daerah yang lebih aman dan dengan tujuan memperbaiki keadaan ekonomi mereka.

Keberadaan etnis Banjar sendiri ketika terjadi migrasi besar-besaran yang melanda Nusantara sebelumnya dikenal dengan sebutan Proto Melayu dan setelah itu dikenal dengan sebutan Deutro Melayu. Proto Melayu dan Deutro Melayu ini sama-sama membawa kebudayaannya masing-masing. Migrasi besar-besaran yang melanda Nusantara pun mengalami perpindahan yang menyebabkan adanya pergeseran-pergeseran budaya mereka (Syafiruddin dkk, 1996:18).

Dengan adanya migrasi besar-besaran yang melanda Nusantara lantas membuat masyarakat Banjar yang berada di Kalimantan memutuskan untuk bermigrasi ke daerah tertentu yang ada di Indonesia. Khususnya di Sumatera Utara ini. Untuk migrasi ke Sumatera Utara bukanlah hal yang mudah dilakukan bagi masyarakat etnis Banjar. Mereka butuh perjuangan dan kesabaran agar sampai ke tujuan yang mereka harapkan dapat membuat perubahan bagi kehidupan mereka mendatang.

Etnis Banjar yang berasal dari Kalimantan awal bermigrasi di Sumatera Utara hanya di wilayah tertentu saja, yaitu di daerah Kabupaten Langkat, Deli Serdang, Serdang Bedagai, Asahan dan Labuhan Batu. Etnis Banjar yang berasal 
dari Kalimantan Selatan tidak langsung ke Kabupaten Asahan. Seperti yang dikemukakan oleh Soedjito Sosrodihardjo, (57:2009) bahwa etnis Banjar yang berada di Kabupaten Asahan awalnya mereka adalah pelaut dan pedagang antar pulau, yang kemudian mereka menetap di Pantai Timur Aceh dan di Kabupaten Langkat. Kemudian mereka menyisir pantai dan memutuskan untuk mendarat di Kabupaten Asahan. Karena etnis Banjar terkenal dengan jiwa petani dan dagangnya sehingga di Kabupaten Asahan etnis Banjar bertani dan Bedagang. Jumlah etnis Banjar yang mendarat di Kabupaten Asahan juga dikatakan tidak banyak. Karena sebagian dari mereka menetap di daerah khusus lain di Sumatera Utara ini.

Adapun yang menjadi faktor pendorong kedatangan etnis Banjar ke Desa Teladan Kecamatan Tinggi Raja Kebupaten Asahan ini dikarenakan di daerah asal orang Banjar yaitu di Kalimantan terjadi perang Banjar di awal abad ke-20 yaitu pada tahun 1905. Orang Banjar terpaksa melakukan migrasi karena Sultan Muhammad Seman yang menjadi raja di Kerajaan Banjar itu mati syahid di tangan Belanda. Dengan adanya perang tersebut wilayah mereka tidak stabil. Mereka sulit untuk memenuhi kebutuhan sehari-hari mereka dan ekonomi orang Banjar. Apalagi daerah orang Banjar kurang produktif untuk pertanian karena sebagian besar merupakan rawa-rawa dan hutan. Hal ini menyebabkan lumpuhnya perekonomian dan pertanian orang Banjar. Karena orang Banjar merasa ketakutan tidak bisa bisa bertahan hidup di daerah asalnya yang disebabkan perang tersebut sehingga orang Banjar memutuskan untuk bermigrasi ke daerah yang lebih aman yang ada di Sumatera Utara, salah satunya yaitu di desa Teladan Kecamatan Tinggi Raja Kabupaten Asahan.

Setiap daerah tentunya memiliki letak geografis yang menjadi daya tarik yang mempengaruhi masyarakat yang tinggal di daerah tersebut. seperti pada masyarakat etnis Banjar yang berada di Desa Teladan. Mereka memiliki daya tarik khusus terhadap letak geografis Desa Teladan. Selain daerahnya subur ternyata masyarakat etnis Banjar melakukan migrasi ke Desa Teladan menghemat biaya hidup orang Banjar yang sebelumnya bermigrasi di daerah perkebunan yang ada di Tinggi Raja setelah terjadi perang di daerah asalnya di Kalimantan. 
Etnis Banjar adalah penduduk yang dominan berada dalam wilayah provinsi Kalimantan Selatan, kedati juga terdapat etnis Banjar sebagian tersebar di wilayah Kalimantan Tengah. Mayoritas orang Banjar memeluk agama Islam dan berbahasa daerah Banjar yang dominan kosakatanya adalah melayu. Sedangkan Banjar adalah istilah untuk menyebut penduduk yang mendiami daerah yang sekarang menjadi provinsi Kalimantan Selatan. Pada mulanya "Banjar" adalah sebutan kampung yang dihuni oleh suku Melayu dan kata Banjar itu sendiri berasal dari kata Banjarmasih yang berarti kampung-kampung melayu (Faisal Rizal (2010:41).

Adapun untuk menganalisis proses adaptasi masyarakat etnis Banjar di Desa Teladan, penulis akan menggunakan teori adaptasi, yang dimana dapat dilihat dari strategi-strategi adaptasi. Strategi-strategi adaptasi adalah cara-cara yang dipakai perantau untuk menghadapi rintangan-rintangan yang mereka hadapi dan untuk memperoleh suatu keseimbangan positif dengan kondisi-kondisi latar belakang perantauan, Whitten, Graves dan Berger dalam Usman Pelly (2013:99).

Dalam beradaptasi tentulah akan menghadapi yang namanya rintangan dan keseimbangan positif agar dapat diterima dilingkungan masyarakat. Keseimbangan positif tersebut tentunya dengan cara beradaptasi yang baik. Sama halnya seperti yang dilakukan etnis Banjar dalam beradaptasi dengan etnis lainnya yang berada di Desa Teladan yaitu etnis Jawa dan etnis Batak. Etnis Banjar beradaptasi dengan cara mematuhi peraturan yang ada di Desa Teladan, serta harus ramah dan saling tolong-menolong terhadap masyarakat etnis lainnya. seperti dalam mengelolah lahan kosong milik etnis Banjar, dalam hal ini orang Banjar tidak sendiri ataupun tidak memakai jasa orang Banjar saja dalam mengelohah lahannya. Orang Banjar juga memerlukan tenaga etnis lainnya. Dengan demikian orang Banjar terlebih dahulu berinterasi dengan etnis lainnya agar etnis lainnya mau membantu mereka mengelolah lahan milik orang Banjar. Dalam hal ini orang Banjar berinterasksi dengan berbahasa yang etnis Jawa atau etnis Batak mengerti. Disinilah orang Banjar mencoba mempelajari bahasa dari etnis lainnya agar lebih mudah berinteraksi.

Keberadaan etnis Banjar di Desa Teladan merupakan etnis pendatang yang mencoba beradaptasi dengan masyarakat etnis lainnya yang berada di Desa 
Teladan, yaitu etnis Jawa, dan etnis Batak. Dalam waktu yang relatif lama etnis Banjar yang tinggal di Desa Teladan tentulah akan membawa dampak bagi etnis Banjar itu sendiri. orang-orang Banjar yang berada di Desa Teladan telah mampu beradaptasi dengan etnis lainnya yang berada di Desa Teladan. Khususnya yaitu etnis Jawa. Orang juga telah mampu membaur dengan etnis lainnya yang berada di Desa Teladan. Mereka juga dalam kehidupan sehari-harinya sudah tidak lagi membeda-bedakan antar etnis dalam lingkungannya.

Adapun dampak orang Banjar yang tinggal di Desa Teladan terhadap proses adaptasi mereka dengan etnis lainnya di Desa Teladan, yaitu dalam kehidupan mereka sudah banyak mengalami perubahan pada mereka. Perubahan tersebut dapat dilihat dalam bahasa, Sistem kepercayaan, Sistem Mata Pencarian, Kesenian, Bahasa, Sistem ilmu pengetahuan, Sistem Teknologi dan peralatan hidup, dan sistem kekerabatan dan Organisasi Sosial.

Ciri khas orang Banjar ialah bahwa etnis Banjar secara umum dilahirkan sebagai orang Islam, atau bahkan orang Banjar itu beragama Islam. Meskipun mereka aslinya dari suku Dayak Nganju, tetapi apabila mereka menganut agama Islam, mereka merasa menjadi orang Banjar (H.A Gazali Usman, 1996:26). Dengan orang Banjar menganut agaam Islam mereka yakin bahwa mereka adalah orang Banjar yang sebenarnya.

Mayoritas agama yang dianut oleh masyarakat etnis Banjar yang ada di Desa Teladan adalah agama Islam seperti etnis Banjar yang ada di Kalimantan Selatan, agama Islam telah tumbuh dan berkembang dalam segala aspek kehidupan etnis Banjar, dan sudah menjadi ciri dan identitas masyarakat etnis Banjar sejak berabad-abad lalu, etnis Banjar yang bermigrasi ke daerah lain dari daerah asalnya tetap membawa agama Islam sebagai agama yang mereka anut. Karena etnis Banjar ini sangat fanatik dengan agamanyanya. Sehingga pantang bagi mereka untuk tidak membawa agama asli mereka ke tempat wilayah mereka sekarang tinggal. Dan mereka akan tetap memperjuangkan agamanya.

Seperti halnya yang dikemukakan oleh (monika Juniar Siahaan, 2011:42) yaitu kentalnya unsur nilai Islam dan Filosofi suku Banjar yaitu "Haram Manyarah Waja Samapi Kaputing”. Yang mengandung makna bahwa pelaksanaan syariat 
Islam di dalam segala aspek kehidupan. Apapun yang terjadi bagi masyarakat Banjar haram hukumnya jika setiap individu tidak melaksanakan hambatan dan perlawanan dari pihak luar, maka diharuskan untuk memperjuangkan syariat Islam dan haram untuk menyerah.

Dari paparan diatas diuraikan bahwa orang Banjar sangat menjujung tinggi agamanya. Dan dimanapun mereka berada harus tetap membawa agamanya dan memperjuangkan syariat agamanya. Bagi orang Banjar juga menyatakan haram hukumnya untuk menyerah dalam memperjuangkan agama mereka, khususnya mereka yang beragama Islam tersebut.

Walaupun hal tersebut dilakukan oleh dilakukan kebanyakan orang Banjar yang migrasi kedaerah lain dari Kalimantan, namun berbeda pula dengan orang Banjar yang berada di Desa Teladan. Orang Banjar yang berada di Desa Teladan mereka memang beragama Islam, dan tetap membawa agamanya dari asal mereka yaitu Kalimantan. Namun dahulunya orang Banjar yang datang di Desa Teladan menganut agama Islam aliran NU (Nahdlatul 'Ulama), tetapi setelah lama menetap di Desa Teladan sekarang Orang Banjar ada yang menganut agama Islam aliran Muhammadiyah.

Dampak dari sistem mata pencaharian etnis Banjar di Desa Teladan yaitu sudah bercampur dengan mata pencaharian lainnya, yang dahulunya orang Banjar dikenal sebagai orang yang ahli dibidang pertanian dan dagang sekarang masyarakat etnis Banjar yang berada di Desa Teladan ada yang mata pencahariannya sebagai tukang bangunan dan ternak sapi serta kambing. Namun masih tetap ada yang bermatapencaharian sebagai petani dan pedagang. Hanya saja tidak semua masyarakat Banjar di Desa Teladan Berprofesi sebagai petani dan pedagang. Dikarenakan tuntutan ekonomi dan keadaan alam yang memang mendukung untuk mereka berahli profesi tersebut.

Adat istiadat atau tradisi etnis Banjar merupakan hasil dari asimilasi sejak berabad-abad. Adat istiadat atau tradisi orang Banjar dapat dilihat orang Banjar khususnya dalam bentuk kesenian, tarian, musik, pakaian, permainan dan upacara tradisional. Adat istiadat etnis Banjar dapat disaksikan melalui berbagai pentas kesenian etnis Banjar dan yang sering ditampilkan dalam acara-acara resmi, seperti 
tari-tarian dan lagu Banjar. upacara adat Banjar juga biasanya dilakukan dalam rangka melaksanakan pesta perkawinan, kelahiran, dan peringatan peristiwa penting lainnya juga dilaksanakan.

Namun hal ini berbeda dengan adat Istiadat atau tradisi yang dibawa etnis Banjar di Desa Teladan tampaknya tidak berjalan dengan baik sekarang ini. Karena orang-orang Banjar yang membawa adat istiadat tersebut sudah meninggal dunia dan keturunan mereka sudah tidak memahami adat dari budaya Banjar itu sendiri. mereka memutuskan untuk meninggalkan adat istiadat mereka karena terdapat beberapa alasan, salah satunya yaitu pernikahan. Adat istiadat mereka lambat laun hilang dikarenakan sebagian dari keturunan mereka terjadi perkawinan antar suku. Secara otomatis mereka akan mengikuti adat dari keluarga baru mereka. Apalagi jika menikah dengan etnis jawa yang merupakan etnis asli dari Desa Teladan.

Bahasa merupakan salah satu cara yang digunakan untuk berkomunikasi ataupun berinteraksi. Dalam kehidupan sehari-hari tidak bisa terlepas dari interaksi dan komunikasi. Menggunakan bahasa tergantung dimana melakukannya, misalnya dalam menggunakan bahasa daerah atau bahasa persatuan yaitu bahasa Indonesia. Namun hal ini berbeda dengan masyarakat etnis Banjar yang ada di Desa Teladan sekarang ini. Dalam berbahasa mereka sudah tidak lagi menggunakan bahasa asal mereka. Karena orang Banjar sekarang sudah tidak memahami bahasa Banjar. Hal tersebut dikarenakan orang tua yang mengerti bahasa Banjar sudah meninggal dunia dan anak dari keturan orang Banjar tersebut banyak yang tidak memahaminya.

pengetahuan lokal yang didapat oleh orang Banjar di daerah asal mereka sudah tidak dijalankan lagi di Desa Teladan Kecamatan Tinggi Raja. Orang Banjar sudah mengikuti bagaimana sistem bertani dan berdagang orang Jawa yang ada di Desa Teladan. Dan tidak ada waktu-waktu tertentu dalam beraktivitas dalam bertani. Dalam berdagang juga orang Banjar yang ada di Desa Teladan sekarang ini tidak menghiraukan lagi pulang berdagang dibawah jam 6 sore. Bahkan sekarang orang Banjar berdagang keliling pulang hingga larut malam tidak menjadi permasalahan bagi orang Banjar yang ada di Desa Teladan Kecamatan tinggi Raja Kabupaten Asahan. 
Masyarakat etnis Banjar yang ada di Desa Teladan sudah mengenal teknologi dan peralatan hidup modern yang didominasi dengan teknologi. Yang dahulunya mereka tidak mengenal teknologi sekarang sudah mengenal dan sudah memakai peralatan hidup yang didominasi dengan teknologi berupa blender sebagai pengganti gilingan bumbu, dan alat modern lainnya mereka sudah banyak menggunakannya. Dalam hal ini tentu membawa dampak positif bagi masyarakat etnis Banjar yang ada di Desa Teladan. Dari mereka belum mengenai teknologi dan peralatan hidup modern mereka sekarang sudah mengenalnya, dan bahkan mereka telah memakainya dikehidupan sehari-hari mereka untuk mempermudah pekerjaan rumah tangga mereka.

Etnis Banjar yang ada di Desa Teladan, mereka sudah tidak mengenal dan bahkan tidak mengetahui yang namanya silsilah dalam keluarga mereka. Penyebutan dalam keluarga mereka atau disebut dengan tuturan bila orang Jawa, mereka sudah mengikuti silsilah keluarga dari orang Jawa. Sama halnya dengan orang Jawa, bagaimana silsilah keluarga orang Jawa begitulah silsilah keluarga orang Banjar yang ada di Desa Teladan.

Tidak ada organisasi khusus orang Banjar di Desa Teladan, tetapi orangorang Banjar mengikuti Perwiritan Yasin yang diadakan di Desa Teladan, Perwiritan tersebut terdiri dari Perwiritan laki-laki, dan Perwiritan perempuan. Namun Perwiritan tersebut anggotanya bercampur dengan etnis yang ada di Desa Teladan. Tidak hanya etnis Banjar saja, etnis Jawa dan Batak juga ikut di Perwiritan Yasin tersebut.

\section{PENUTUP}

Sejarah keberadaan etnis Banjar di Desa Teladan Kecamatan Tinggi Raja Kabupaten Asahan terdapat dua faktor yang menyebabkan mereka bermigrasi dari daerah asalnya, yang pertama adalah faktor pendorong, yakni terjadinya perang Banjar di daerah asal mereka. Akibat dari perang ini terjadi ketidakstabilan dalam kehidupan masyarakat Banjar yang ada di Kalimantan, hal ini menyebabkan mereka meninggalkan daerahnya untuk mencari daerah lain yang lebih aman dan layak untuk kehidupannya, salah satunya di Desa Teladan Kecamatan Tinggi Raja 
Kabupaten Asahan. Kedua, yaitu Faktor penarik, adanya penawaran lahan kosong dengan harga yang relatif murah dan tanah yang subur untuk dijadikan lahan pertanian serta memperkecil biaya hidup orang Banjar. Hal ini menyebabkan banyak orang Banjar yang datang ke Desa Teladan untuk bertani dan berdagang dari hasil pertaniannya, dengan demikian mereka berharap agar kehidupannya lebih baik lagi dari sebelumnya.

Proses adaptasi etnis Banjar di Desa Teladan Kecamatan Tinggi Raja Kabupaten Asahan berlangsung dengan baik. Etnis Banjar mudah menyesuaikan diri dengan masyarakat yang ada di Desa Teladan. Dalam berinteraksi dengan masyarakat setempat etnis Banjar menyesuaikannya dengan menggunakan Bahasa Indonesia, bahkan bahasa daerah dari lawan mereka berbicara. Seperti jika berbicara dengan orang Jawa orang Banjar akan mencoba berbahasa Jawa.

Dampak adaptasi bagi etnis Banjar yang ada di Desa Teladan Kecamatan Tinggi Raja Kabupaten Asahan dapat dilihat pada 7 unsur kebudayaan, yaitu pada sistem kepercayaan, sistem mata pencaharian, kesenian, bahasa, sistem ilmu pengetahuan sistem teknologi dan peralatan hidup, serta sistem kekerabatan dan organisasi sosial semuanya sudah mengalami perubahan karena sudah terakulturasi dengan budaya etnis yang ada di Desa Teladan, khususnya etnis Jawa. Etnis Banjar lebih memilih meninggalkan budayanya dengan berahli pada budaya etnis Jawa yang mereka anggap mudah untuk dilakukan.

\section{REFERENSI}

Departemen Pendidikan dan Kebudayaan, (1983). Sistem Kesatuan Hidup Setempat Daerah Kalimantan Selatan. Jakarta

Kecamatan Tinggi Raja Dalam Angka. (2018). Badan Pusat Statistika Kabupaten Asahan.

Maoleong, Lexy J.(2012). Metodologi Penelitian Kualitatif. Bandung: PT Remaja Rosdakarya

Pelly, Usman.(1994). Urbanisasi dan Adaptasi: Peranan Misi Budaya Minangkabau dan Mandailing. Jakarta: LP3ES.

Siahaan, Juniar, Monika. Sejarah Migrasi Suku Banjar ke Kecamatan Mengkudu Kabupaten Serdang Tahun (1909-2010). Medan: Universitas Negeri Medan

Sutisna \& Pajriah. 2012. Eksistensi Masyarakat Etnik Sunda di Desa Cimaru Kecamatan Patimuan Kab. Cilacap. Ciamis: Universitas Galuh. 